\title{
Abiotic Stress Tolerance-Progress and Pathways of Sustainable Rice Production
}

\author{
Manzoor H. Dar 1,*(D), Dilruba A. Bano ${ }^{2}$, Showkat A. Waza ${ }^{3} \mathbb{D}_{\text {, Najam W. Zaidi }}{ }^{1}$, Asma Majid ${ }^{4}$, Asif B. Shikari ${ }^{3}$, \\ M. Ashraf Ahangar ${ }^{3}$, Mosharaf Hossain ${ }^{1}$, Arvind Kumar ${ }^{1}$ and Uma S. Singh ${ }^{1}$
}

1 International Rice Research Institute (IRRI-India), NASC Complex, New Delhi 110012, India; n.zaidi@irri.org (N.W.Z.); m.hossain@irri.org (M.H.); a.kumar@irri.org (A.K.); u.singh@irri.org (U.S.S.)

2 State Department of Agriculture, Government of Chhattisgarh, Shankargarh 497118, India; dabgpb@gmail.com

3 Mountain Crop Research Station (Sagam), SKUAST Kashmir, J\&K, Anantnag 192124, India; sahmad777@gmail.com (S.A.W.); asifshikari@gmail.com (A.B.S.); mashrafjs@gmail.com (M.A.A.)

4 Division of Genetics and Plant Breeding, SKUAST Kashmir, J\&K, Wadura 193201, India; asmamajid173@gmail.com

* Correspondence: seedmanzoor.dar@gmail.com

Citation: Dar, M.H.; Bano, D.A.; Waza, S.A.; Zaidi, N.W.; Majid, A.; Shikari, A.B.; Ahangar, M.A.; Hossain, M.; Kumar, A.; Singh, U.S. Abiotic Stress Tolerance-Progress and Pathways of Sustainable Rice Production. Sustainability 2021, 13, 2078. https://doi.org/10.3390/ su13042078

Academic Editor: Domenico Ronga Received: 12 December 2020

Accepted: 8 February 2021

Published: 15 February 2021

Publisher's Note: MDPI stays neutral with regard to jurisdictional claims in published maps and institutional affiliations.

Copyright: (c) 2021 by the authors. Licensee MDPI, Basel, Switzerland. This article is an open access article distributed under the terms and conditions of the Creative Commons Attribution (CC BY) license (https:// creativecommons.org/licenses/by/ $4.0 /)$.

\begin{abstract}
Rice is globally a major food crop and its production has progressively been affected by various types of abiotic stresses especially drought, flooding, salinity, heat and cold in most of the cultivable rice ecosystems. The incidence, intensity and duration of these stresses are anticipated to aggravate due to climate change consequences, demanding resilient yields in these situations to be essential. Present paper deals with reviewing various types of abiotic stresses and their mitigation strategies for enhancing and stabilizing rice production in stress prone areas. Review of available literature pertaining to the study area has been used as research methodology for this paper. The available literature suggests that stress-tolerant varieties can serve as the most viable strategy to contribute in coping with the problem of abiotic stresses. Although, good progress has been made in the development of stress-tolerant rice varieties (STRVs) and incessant efforts are being made to spread these varieties in target areas, adoption by farmers is yet to meet expectations. Advantage, affordability, awareness and availability are the main factors responsible for adopting of any technology. The adoption of stress-tolerant varieties has not reached its potential, predominantly due to the lack of awareness and non-availability of seeds amongst farmers. Strategic and intentional collaborations should be ensured for scaling the sustainable delivery and diffusion of STRVs. A promotional roadmap that ensures the linkages between private and public seed sectors remains the key factor for its successful adoption. Similarly, strengthening of formal, informal and semi-formal seed systems is crucial to accelerate the dissemination of these varieties. There is an imperative need to create strategic plans for the development of varieties possessing multiple stress tolerance. Significant investments for sustainability of rice production in stress prone areas form the essential component of long-term agricultural development. The sooner these investments and strategies are accomplished, the greater the gains are expected.
\end{abstract}

Keywords: food security; rice; abiotic stresses; stress tolerant rice varieties; strategic planning

\section{Introduction}

The vulnerability of any society towards poverty and hunger is a multifaceted phenomenon. It depends upon the population structure, technological developments, policy implications, social behavior, land and water use patterns, economic status and cultural composition [1]. The resource-poor farmers in stress-prone areas are highly vulnerable to poverty and hunger. The stresses such as drought, submergence, salinity, heat and cold lead to the frequent destruction of crops imposing farmers to leave their fields fallow, and thereby converting them to dependent laborers [2]. The farmers from stress prone areas are 
frequently subjected to chronic deprivations such as hunger and malnutrition, poor health, limited education, marginalization, lacking the resilience to cope with economic setbacks and natural disasters. Women, children and elderly in particular are highly vulnerable to shocks driven by abiotic stresses [3]. Moreover, the recurrent occurrence of these shocks reduces the propensity of farmers to adopt new and profitable technologies, increasing the vulnerability and depleting their capability to overcome hunger and poverty [4] The abiotic stresses disproportionately affect the underprivileged farmers, resulting in reduction of their consumption, withdrawing their children from schools, and inflicting them to emigrate for source of livelihood to meet the instant needs [1].

Due to long-term adverse effects of climate change, the frequency, intensity and duration of abiotic stresses are anticipated to step-up in the coming years of this century, posing serious threats to crop production and global food security [5]. Besides, abiotic stresses have been aggravated due to the constant population growth along with urbanization and the need to obtain a range of services from agriculture in addition to food production [6]. The present scenario of farming in stress prone areas require major innovations to transform the existing practices of food production, distribution and consumption. The agricultural systems in these areas need to be modified for addressing the existing challenges to ensure the pertinent increase in food production [7]. Farmers will have to produce substantially large amount of food on less land, with less water, using less energy, fertilizers and pesticides without disturbing the ecological systems [8]. The scientific community need to play an important role in ascertaining the strategic investments in stress prone areas to set up resilient agricultural production systems, reduce greenhouse gas emissions, ensure well organized use of resources and safeguard adequate nutrition. [3].

The present need is to enhance the productivity of major food crops in the regions highly prone to various types of environmental perturbations [9]. Among the main food crops, rice cultivation is highly impacted by various ecological constraints with about one-third of the 700 million poor affected in rainfed lowlands of Asia alone [10]. Existing and anticipated food demands necessitate a substantial enhancement in the productivity of this crop in the stress prone ecologies where soils, temperature and water control are suboptimal [11]. Investment, innovation and empowering the world's most vulnerable populations is required to establish a rice production system that adapts to climate change, without disturbing the sustainability of our natural resource base. Smashing investments for the sustainability of rice production in stress prone areas form the essential component of long-term economic development. The sooner these investments are accomplished, the greater the gains are expected [12]. The present paper aims to consolidate the research on various types of abiotic stresses and their mitigation strategies for enhancing rice production in stress prone areas. We do this by providing an extensive review about the major abiotic stresses in rice, their distribution, area covered, the most sensitive stages, extent of losses, present status and future anticipations. Development, dissemination and adoption of stress tolerant varieties as the most coherent approach to deal with abiotic stresses is being discussed in view of the available literature. The mechanisms and genes responsible for stress tolerance has also been detailed. The social impacts and barriers in adoption of STRVs has also been discoursed. The strategic planning and adoption of various research-based approaches to ensure the sustainability of rice production has been dealt in view of the long-term agriculture developmental goals.

\section{Methodology}

Review of available literature about the study area has been used as a research methodology for this paper. An extensive review identifies the current gaps in scientific literature, integrate various studies, develop new understandings, generalize research outcomes and anticipate research inferences [13-15]. The research question in the present study is to understand the potential risks caused by various abiotic stresses in rice and to interpret various mitigation strategies. Therefore, the peer-reviewed literature for the terms "food security", "abiotic stresses in rice", "drought", "flooding", "salinity", "heat", "cold", 
"stress tolerant rice varieties" and "mitigation strategies to cope with abiotic stresses" was searched from different data sources like PubMed, Web of Science, Embase, Google Scholar, AGRICOLA, PubAg and Scopus. The terms were searched either singly or in different combinations. The electronic searching resulted in the documentation of 1891 articles. Most of the research articles were collected from the electronic database sources like Elsevier, Springer, Wiley, Emerald, Taylor \& Francis, and so on. After removing of duplicates, the irrelevant papers were excluded manually from all the papers retrieved through automatic search. During the entire selection process, 87 highly relevant articles were included in the literature review without setting any criteria for the article publication date.

To ensure that no relevant articles had been left out, thorough screening through full text reading followed by forward and backward snowball techniques were used $[15,16]$. The distribution of available literature reveals the evolution of scientific works and reflects the increasing trend in the number of publications over time. A peak in publications was observed in 2017 followed by 2015. The relevant papers were widely distributed among various journals belonging to different research areas like plant physiology, biotechnology, genomics, molecular biology, genetics, plant genetic resources, microbiology, agronomy, environmental sciences, environmental policy, ecology, evolution, abiotic stresses, food security, food safety, water management, extension, economics, rural development, human values, computer sciences, and so on. The papers selected were distributed amongst the authors and the relevant data was extracted through literature review. The data from all the authors were compiled into a single document. After eliminating redundancy, the information was shared amongst the authors to finally modify, add or rearrange the data in a second brief review. After the completion of compilation and manuscript drafting, the "JournalGuide" search engine was used to explore the appropriate journal for publication.

\section{Results and Discussion}

\subsection{Major Abiotic Stresses in Rice}

Rice is globally the most important food crop that serves as the main source of calories for more than half of the world's 7 billion people. Its production has increasingly been exposed to the losses caused by abiotic stresses like drought, flooding, salinity, heat and cold in most of the cultivable rice ecosystems [17]. The frequency, intensity and duration of these stresses is expected to rise due to the progressive effects of climate change [18]. Among abiotic stresses, drought or scarcity of water is most devastating for rice cultivation in rainfed ecosystems. Submergence of rice plants for one to two weeks due to flash flooding is another major constraint prevailing mainly in rainfed lowlands [19]. The long duration cultivars usually come across with flooding at early stages followed by drought during flowering, resulting in huge yield losses [20]. Similarly, salinity which is characterized by high concentration of soluble salts is another widespread soil problem next only to drought and acts as a serious limitation for rice production worldwide [21]. Heat stress is nowadays emerging as a serious threat to rice production in view of the global climate change [22]. It restricts the plant growth, interrupts its metabolic activities and limits production [23]. Likewise, low temperature is a common problem for rice cultivation in temperate regions as well as high-altitude environments in tropical and subtropical areas. Cold stress adversely affects the rice crop at germination, vegetative growth and reproductive stages, leading to significant yield losses [24]. Sometimes, the rice crop comes across with multiple stresses (like salinity along with drought, drought followed by submergence), leading to huge crop losses. The improvement in combined tolerance to various types of abiotic stresses would substantially increase rice productivity while sustaining water resources and soil quality [25].

\subsubsection{Drought}

Drought acts as a major limitation for rice production. As per the estimates, more than half of the global rice area is suffering from drought of various intensities [17,26-28]. Rice grain yield as well as vegetative growth is seriously affected by drought [29]. Reduction in 
test weight, grain dimensions and rate of seed-setting are frequently noticed under insufficient moisture conditions [30,31]. Drought stress restricts floret emergence, causes spikelet infertility, lead to low test weight and finally results in reduced grain yield [32,33]. The decline in yield may be due to drought induced reduction in $\mathrm{CO}_{2}$ assimilation, decreased stomatal efficacy, reduced efficiency of photosynthetic machinery, diminished leaf size, condensed stem extensions, decline in water use efficiency, suppressed activities of photosynthetic assimilate synthesizing enzymes and inappropriate distribution of sugars [34]. The extent of yield reduction varies with the length of drought period, the stage of crop growth and intensity of the stress [31,35].

\subsubsection{Submergence}

Submergence is one of the key limitations for rice cultivation especially in the years and areas of high precipitation. More than $16 \%$ of the global rice area is prone to flooding [36,37]. Flash floods resulting in complete immersion of the plants in water for about two weeks is one of the most frequent constraints for rice cultivation in rainfed lowlands of south and south-east Asia [38]. In India, approximately one-third of the paddy area is vulnerable to submergence with an average yield of only $0.5-0.8 \mathrm{t} \mathrm{ha}^{-1}$ compared to national average of $2.6 \mathrm{t} \mathrm{ha}^{-1}$ [39]. The enduring adverse effects of climate change are likely to increase flooding incidences, a major threat for sustainable rice production in near future [40]. Many areas are anticipated to witness an increase in flooding as a result of sea level rise, irregular pattern of rainfall distribution and projected increase in rate of occurrence and intensity of extreme weather events [19].

Although aerobic crops cannot survive water logging, paddy can subsist in shallow standing water due to its extensive aerenchyma which can maintain oxygen supply to the roots [41]. However, most rice cultivars cannot withstand flooding for more than 7 days [42]. Flash flooding driven complete submergence limits gaseous exchange, thus impeding growth processes, resulting in death and decay of plants [41,43]. The degree of submergence induced damage depends on the depth and duration of flooding as well as on the geography of land and flood water conditions [44,45].

\subsubsection{Salinity}

Salinity refers to condition of the soil or water resulting due to higher concentrations of various salts such as $\mathrm{NaCl}, \mathrm{MgSO}_{4}, \mathrm{CaSO}_{4}, \mathrm{MgCO}_{3}$ and $\mathrm{CaCO}_{3}[46,47]$. Salinity can develop naturally or may be anthropogenic. Irrigation and widespread clearance of vegetation are the two major human activities that accelerate the accumulation of salts in soil surface [48]. It is being anticipated that half of the cultivable area will be salt affected by the mid of twenty-first century [49]. Among the cereals, rice is considered to be the most salt sensitive crop and every year millions of hectares in South and Southeast Asia are left uncultivated because of salinity. Salinity response in rice is a multifaceted phenomenon, involving coordinated and tissue-specific processes to enable its growth on affected soils [50].

The damage to rice crop depends on the extent of salinity, exposure duration, genotype, growth stage, water regime, soil physical properties, temperature and solar radiations [51-53]. Salinity causes stomatal closure, increase in leaf temperature, reduction in photosynthesis, loss of biomass, partial sterility and inhibition of shoot elongation, all these manifesting towards the reduction in yield [54,55]. Rice crop is highly sensitive towards salinity during early seedling and reproductive stages. It has been observed that rice crop shows tolerance during germination, active tillering and towards maturity. Salinity stress at seedling stage causes whitened tips of young leaves, leaf chlorosis, plant stunting, low tillering and irregular plant survival [56]. At reproductive stage, the stress reduces number of spikelets, effective tillers, spikelet fertility, panicle length and panicle branching [57].

\subsubsection{Heat}

Heat stress, characterized by prevalence of high temperature is one of the major abiotic constraints for rice production, next only to drought and salinity [58]. The phenomenon of 
global warming resulting from the continuous emission of greenhouse gases acts as a major source of increase in atmospheric temperature [59]. The global emission of greenhouse gases due to human activities is likely to increase in ensuing years, thereby contributing towards the further increase in temperature [60]. It has been estimated that the rise in average temperature by $1{ }^{\circ} \mathrm{C}$ declines the rice yield by 4 to $10 \%$ [61]. Although rice maintains its normal growth and development at 27 to $32{ }^{\circ} \mathrm{C}$, temperatures above this range drastically affect all stages of the plant's life cycle [62], the most critical being $33^{\circ} \mathrm{C}$ during flowering [63]. Booting and flowering are the most heat sensitive stages leading to complete sterility in rice [64].

High temperature at flowering leads to abnormal pollination, resulting in poor seed set and low grain quality $[65,66]$. To ensure fertility at anthesis under high temperatures, scientists are employing the strategies of escape, avoidance, and tolerance [67]. During vegetative growth, heat stress can lead to leaf discoloration and accelerated development, leading to low yield in sensitive cultivars. Excessive heat causes irreversible damage by reduction in metabolic activities, rate of photosynthesis, leaf area, water-use efficiency, plant growth and yield $[68,69]$. The different growth stages of rice show differential sensitivity towards enhanced day and night temperatures. Enhanced nocturnal temperatures increase respiration rates, thereby affecting the metabolism and resulting in reduction of yield [70].

\subsubsection{Cold}

Rice is a cold-sensitive crop and among the abiotic stresses, low temperature acts as a main limiting factor for production of this crop under temperate conditions and high elevation environments. Due to the impact of ongoing climate change, the frequency of extreme low temperature events has increased since last few decades [25]. The effects of reduced temperatures on rice crop depend on the developmental stage, intensity of cold, genetic constitution of the variety and time of exposure [71,72]. Cold stress badly affects the growth and development of rice plants at germination, vegetative and reproductive stages, causing severe reduction in yield. At germination, cold stress reduces both percentage and speed of germination. At vegetative stage, low temperatures affect seedling vigor leading to non-uniform plant height [73,74]. The most sensitive phase towards low temperature damage in rice is booting stage, followed by flowering [75].

Low temperature at booting and flowering stages declines the plant growth and causes significant reduction in spikelet fertility and increase in susceptibility towards diseases [76]. The degree of reduction in fertility varies across the varieties and with the duration of cold exposure [77]. Japonica genotypes are more tolerant to low temperature than Indicas and thus under high altitude and latitude ecologies, these types of varieties are prevalent [78]. Prolonged exposure to cold causes physiological changes in the rice plant, resulting in decrease in total chlorophyll content, inhibition of photosynthetic activity and oxidative stress [79]. This results in chlorosis and necrosis in rice leaves [80,81].

\subsection{Stress Tolerant Rice Varieties (STRVs) for Ensuring High Yields under Stress}

Most of the rice farmers in stress-prone areas show more dependence on locally available low yielding traditional cultivars and landraces which are relatively tolerant to abiotic stresses. In some places, farmers have altogether left paddy cultivation to leave their fields fallow in the wet season [82]. Although, some farmers cultivate modern and improved rice varieties due to their high yield potential, these improved varieties under unfavorable conditions suffer huge yield losses due to their inability to withstand stresses [2]. Development, dissemination and adoption of stress tolerant high yielding rice varieties possessing better quality can act as the most coherent approach to deal with the problem of abiotic stresses [83]. High yielding STRVs has the potential to increase and stabilize rice productivity in the unfavorable ecosystems that did not benefit from the first green revolution [82]. These varieties have enabled the farmers to grow rice in the areas where its cultivation has been abandoned due to the frequent occurrence of abiotic stresses [84]. The present need is to develop the climate-resilient varieties with multiple 
stress tolerance to address the uncertainty posed by climate change and its impact on rice in future [12].

\subsubsection{Drought Tolerant Rice Varieties}

The need for development of drought tolerant STRVs has been recognized since long to ensure sustainable rice production in rainfed areas [12]. Identifying rice genotypes and breeding lines with high levels of drought tolerance, and subsequently using them in breeding programs has been one of the major challenges in rice research [85]. Progress in breeding for drought tolerance has been slow due to the complex genetic expression of drought tolerance, and difficulties in bringing various drought-tolerance related traits together along with high yield under well-watered conditions [86]. Research on varietal development for drought tolerant rice was started in 1960s by International Rice Research Institute (IRRI), but the promising results appeared only about a decade back when some lines (like IR 74371-54-1-1, IR 74371-46-1-1and IR 74371-70-1-1) showing drought tolerance were developed by IRRI. These genotypes exhibited exceptionally desirable performance in India, Nepal and Bangladesh [12]. Under the intense stress, where most of the high yielding cultivars got totally succumbed, the drought tolerant lines showed yield of about 0.8-1.0 $\mathrm{tha}^{-1}$. Even under non-drought conditions, the tolerant lines surpass the popular rice varieties in drought prone areas $[30,86]$. Likewise, the IR64 QTL lines were developed that outperformed IR64 by 0.5 to $1.8 \mathrm{t} \mathrm{ha}^{-1}$ under different intensities of drought [87]. Similarly, the varieties like CR Dhan, Abhishek and Sushk Samrat has also been recognized for their ability to stabilize rice production in rainfed lowlands of eastern India [10]. Moreover, in different areas of South Asia, different drought tolerant cultivars have been promoted (for example, DRR 42, 44 in India; BRRI Dhan 66, 71 in Bangladesh and Sukha Dhan 4, 5 in Nepal). The drought tolerant line IR74371-70-1-1 has been promoted under three different names in three countries: as Sahbhagi Dhan in India, as BRRI Dhan 56 in Bangladesh and as Sukha Dhan 3 in Nepal [88]. This reveals the worth of this genotype to exhibit yield advantage across a wide range of ecologies. Sahbhagi Dhan shows distinct yield advantage under drought without any yield penalty in normal conditions.

\subsubsection{Submergence Tolerant Rice Varieties}

Rapid progress has been made in developing flooding tolerant rice varieties and continuous attempts are being made to disseminate these varieties to farmers in unfavorable rice growing ecologies [84]. Incorporating submergence tolerance into high yielding popular rice cultivars has been recognized to be the most effective approach to alleviate the effects of submergence [89]. Using marker assisted breeding (MAB), Sub1 (Submergence tolerance 1) QTL has been incorporated from the local Indian landrace into a mega variety Swarna, which is being widely cultivated in many states of India. The variant of Swarna, named as Swarna-Sub1, can endure complete flooding for over 15 days and recovers well once water is receded [83,90] After thorough evaluation over years in farmers' fields, Swarna-Sub1 was recommended for commercial cultivation in India during 2009 [19]. In the meantime, Sub1 was introgressed in some other rice varieties, popularly cultivated in rainfed and flood-prone areas of South and South-East Asia [17]. Sub1 varieties of rice (e.g., Swarna-Sub1, BR11-Sub1, CR1009-Sub, Sambha Mahsuri-Sub1) have been clearly recognized for their contribution towards enhancing rice productivity in the rainfed lowlands of Bangladesh, India and Nepal [82,91].

Recently, strategies have been focusing for replacing other popular mega varieties with their stress tolerant versions in the suitable target areas. The rationale of this work is that farmers are already well adapted with the popular varieties and introduction of their stress tolerant versions will not entail to inform them about new specifications and cultivation practices [89]. This would lead to easy adoption and popularization of STRVs in initial stage and would also provide the track for totally new varieties to be accepted by farmers $[19,83]$. 


\subsubsection{Salinity Tolerant Rice Varieties}

Development of salt tolerant rice varieties can serve as the most economical and effective approach to enhance crop production in salinity affected ecologies [92]. Although many salinity tolerant landraces are under cultivation, the fact is that these cultivars have poor agronomic features with low yield potential [93]. These landraces are being used as potential donors to enhance the salinity tolerance in otherwise sensitive but popular rice cultivars [94]. Pokkali, a landrace has been observed to show relatively better salt tolerance and thus used as highly potential donor. In this landrace, a major QTL (Saltol) governing salinity tolerance at vegetative stage has been identified on chromosome 1 [95]. Similarly, FL478 (a cultivar derived from crossing between Pokkali and IR 29) is being exploited as a potential donor for salinity tolerance. This genotype possesses enhanced degree of seedling stage salinity tolerance, besides being photoperiod insensitive and flowers earlier than the original Pokkali [96]. Using marker assisted backcross breeding, Saltol and other QTLs has been introgressed in some popular rice varieties (like ADT45, CR1009, Gayatri, MTU1010, PR114, Pusa 44 and Sarjoo 52) to enhance their cultivation in salinity affected areas [17].

Salinity tolerance is a multifaceted phenomenon and requires the combination of independent and/or interdependent mechanisms. The tolerance at one stage is usually independent of the tolerance at other stage [97]. Likewise, salinity tolerance is a polygenic trait independently and/or inter-dependently controlled by different QTLs [98]. Eleven QTLs for salt tolerance were identified on Chromosomes 1, 4, 6, 7, and 9, from the population derived by crossing Nona Bokra and Koshihikari [99]. Similarly, thirteen QTLs for seedling stage salt tolerance in cultivar Changbai10 were identified on chromosomes 1, 5, 6, and 7 [100]. The immense need is to develop rice varieties with multiple QTLs governing salt tolerance at different growth stages.

\subsubsection{Heat Tolerant Rice Varieties}

Enhancing heat tolerance in rice has been one of the major breeding objectives throughout the tropics especially in view of the ongoing climatic change. Wide variation for heat tolerance has been observed among the different cultivars of rice [101]. Among the heat tolerant varieties involves Indica cultivars viz., IR24 and IR36; Japonica cultivars viz., Akitakomachi and Koshihikari; and an aus landrace, Nagina22 (N22) [102]. Landraces which are more adapted to the local environmental conditions could be the potential sources for heat tolerance. The aus indica landrace N22 has been identified as one of the most heat tolerant accessions and it has been used as a check variety for most of heat tolerance studies in rice [103]. The QTLs for heat tolerance from N22 can be introgressed into other varieties for developing the heat tolerant climate resilient rice cultivars [104].

Several major and minor QTLs for high temperature tolerance along with their linked markers have been identified in rice [105]. However, the constraints for developing superior genotypes with heat tolerance is that the trait is governed by small effect QTLs or several epistatic QTLs [66]. Pyramiding several QTLs in the same genetic background using large populations through marker-assisted breeding or genomic selection can be employed to overcome the problem [106-108]. A QTL qHTSF4.1 that increases spikelet fertility by about $15 \%$ at the temperatures higher than $37^{\circ} \mathrm{C}$ has been fine mapped on chromosome 4 [109]. High throughput phenotyping and genotyping approaches such as genome wide association studies (GWAS) and genotyping by sequencing (GBS) can be exploited to tap all the available diversity contributing towards heat tolerance [110-112]. With the advancements in genome editing techniques like CRISPR-Cas9 and TILLING, the crop improvement for heat tolerance can be accelerated $[113,114]$.

\subsubsection{Cold Tolerant Rice Varieties}

The development of cold tolerant rice cultivars is one of the most effective and economical approaches to enhance rice production especially in the areas prone to cold stress [115]. A wide spectrum of variations in cold tolerance has been observed amongst the rice genotypes, reflecting the differences in places of their origin and breeding history. Japonica 
varieties are usually distributed in high elevated ecologies and show better cold tolerance compared to indica [116]. They are thus used as donors in breeding programs for the improvement of cold tolerance [115]. Kalinga-III, CR Dhan 601, Joymati, Kanaklata, K-332 and SR-5 are some of the rice varieties showing tolerance towards cold conditions and are thus cultivated under high altitude ecologies during normal growing seasons and under boro conditions during winters [117-119].

Cold tolerance is a complex trait, highly influenced by environmental factors and controlled by different genes at different growth stages. Considerable efforts have been made for evaluation and mapping of QTLs associated with cold tolerance in rice. Some genes (COLD1, qLTG3-1 and LTG1) governing cold tolerance at the vegetative stage have been identified [120]. Similarly, various low-temperature germinability-associated QTLs have been identified in different populations [121,122]. Jiang et al. [123] identified 11 putative QTLs governing low-temperature germinability on chromosomes 3, 4, 5, 7, 9, 10, and 11. Fewer QTLs have been identified for cold tolerance at bud stage than at the germination stage [124].

\subsection{Social Impact of STRVS}

Most of the stress-prone areas are inhabited by socio-economically disadvantaged farmers possessing marginal to small land holdings with unstable yields. Thus, abiotic stresses affect the unprivileged farmers disproportionately $[19,125]$. The extent of abiotic stresses induced damages are drastic and irreparable. The reason being that the crops are usually in an active growth stage and farmers already have incurred substantial investments in the form of inputs [126]. Moreover, farmers growing rice in stress prone areas are risk-averse and therefore reluctant to use costly farm inputs, thereby resulting in further decline of yield [127]. The cultivation of STRVs encourages the farmers to invest more on inputs due to reduced risks of crop failure. This results in an increase in farm output during all the years, irrespective of the severity of stresses [128-130]. Besides, STRVs represent an important adaptation to climate change that can increase farm productivity and ensure production from the affected land. This leads to optimism that the problems associated with climate change can be dealt partly through the development, dissemination and of adaption of resilient varieties [12].

\subsection{Barriers in the Adoption of STRVS}

Advantage, affordability, awareness and availability (4As) are the main factors responsible for the adoption of any technology (Figure 1). The STRVs reveal better performance during stress as well as non-stress conditions and thus show distinct advantage over non-STRVs [3]. Moreover, no special expenditure needs to be incurred by farmers while adopting STRVs, thus there are no issues of affordability [38]. The adoption of stress tolerant varieties has not reached to its potential, predominantly due to the lack of information (awareness) and non-availability of seeds with farmers [131]. Informational inefficiencies act as main barrier for the adoption of STRVs. Increasing awareness about the worth of new varieties is the first and foremost step for their rapid and large-scale adoption [39]. Proper awareness enhances seed multiplication and marketing by creating the sufficient and continuous demand for quality seed [132].

The relative advantage in performance of rice varieties in farmers' fields may result in their rapid adoption, for the reason that most the farmers procure seeds from neighbors and relatives, and better performing cultivars disseminate fast through exchange once farmers are well informed about their benefits [133]. The informal seed system through exchange and sharing amongst farmers has been an effective strategy for both pre- and post-release dissemination. This process is smooth but slow and highly fragile due to its sensitivity to natural disasters, unpredictable weather changes, and limited capacity of farmers to produce and retain good quality seeds for exchange [134]. Regular access to seeds of climate resilient rice varieties is important to address such challenges and the supply of seeds through business channels is the only sustainable way forward [83]. 
Besides, sustainable use of rice varieties depends critically on the availability of adequate supply of fresh seeds. In particular, if the supply side of the market is limited, relying on farmers to use self-multiplied seeds and efficiently diffuse those seeds amongst themselves is an ineffective and slow strategy [91].

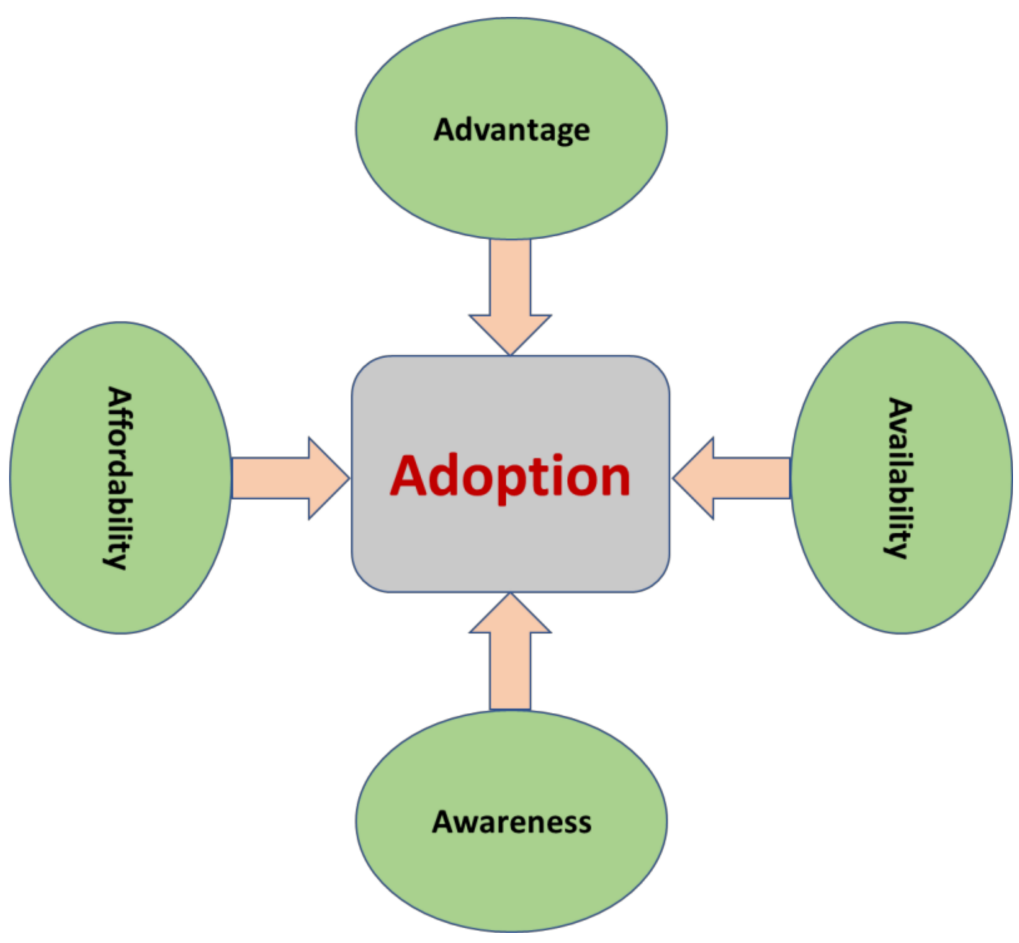

Figure 1. Major determinants for the adoption of STRVs by farmers.

Similarly, some of the farmers are unaware about re-using the seed of STRVs by confusing these with hybrids. This acts as a non-trivial barrier for adoption especially in the regions where hybrids are being extensively grown and widely endorsed by private seed companies [89]. This clearly shows the importance of awareness amongst farmers regarding the need of saving seeds for the next cropping season. The current extension and delivery systems are not successful in delivering a proven stress tolerant technology to farmers in a proper perspective [82]. As a consequence, this technology has yet to be adopted at a scale where it can deliver maximal benefits. Establishment and adoption of a new research-based approaches for proper diffusion and scaling of STRVs is thus needed [134].

\subsection{Strategies for Enhancing Rice Production in Stress Prone Areas}

Strategic planning and adoption of various research-based approaches has the potential to ensure the sustainability of rice production in stress prone areas. These strategies form the essential component of long-term agricultural development.

\subsubsection{Establishing Linkages between Different Stakeholders}

The sustainability of STRVs depend heavily on the level of seed multiplication and participation by seed dealers, seed producers, private and public seed companies, nongovernmental organizations (NGOs), progressive farmers, marketing agents, extension officials, media as well as women led seed groups who can contribute towards the sustainable seed supply for their communities [91]. Therefore, new approaches need to be developed towards working with the public and private stakeholders associated with different arenas of seed. A promotional roadmap needs to be established by ensuring the linkages between private and public seed sector with the institutions that produce breeder seed [135]. 
Formal, informal and semi-formal (NGOs, small farmers clubs) seed systems have complementary tasks in supporting agricultural development. Strengthening all these systems to expedite the upscaling and adoption of new varieties in pipeline is indispensable. Informal seed strengthening helps in pre-release promotion of STRVs and their evaluation through multiple channels for greater feedback generation $[38,82,84]$. The key seed system players need to be brought together to enhance their knowledge about new rice varieties, thereby to improve and speed up seed multiplication, dissemination and adoption [89]. This includes partnerships with local NGO's and private seed companies (small, medium and large) to ensure adequate supply and availability of seed. These partnerships can potentially ensure the sustainable supply and availability of good quality seeds of STRVs [136].

\subsubsection{Engaging Seed Dealers and Agrovets for Delivering Extension Services}

The incentives for wide-scale adoption will not be well aligned unless private sector plays a larger role. Awareness creation through seed dealers, agrovets, distributors and marketing agents of seed companies linked with public and private seed corporations has been found to be very promising for improving the adoption of STRVs [135]. Therefore, instead of delivering information and demonstrations to farmers, delivering these services to seed dealers/distributors has a greater impact on the spread of new varieties. Seed dealers have incentives to spread the information to their customers (i.e., marketing to farmers) because increase in demand translates directly to increased profits for dealers [12,137]. Seed dealers and agro-vets influence the varietal/ seed selection by farmers and thus can play a primary role in dissemination of STRVs especially in areas with poor network of extension services. In addition, dealers have reputations to protect and support their clients, since they deal with the same farmers every year [138]. Therefore, well-informed dealers are unlikely to push the wrong technology upon farmers. In addition to better alignment of incentives, delivering extension services to dealers offers obvious cost advantages as their population being orders of magnitude smaller than the population of farmers [139]. Using dealers' networks for awareness creation and creating seed demand helps in improving SRR (seed replacement rate) of rice in general and of STRVs in particular.

\subsubsection{Deploying Women Self-Help Groups for Dissemination and Sustainability of STRVs}

Establishing a platform in the seed sector at community level by involving enterprising women self-help groups (SHGs) can improve the local availability and delivery of stress tolerant rice in target areas [140]. The rationale behind this approach is that the female farmers boost the spread of awareness and technologies in their community groups, thereby resulting in sustainable processes and practices $[141,142]$. The female farmers as principal agents of change in their communities need to be promoted [140].

Women's groups have immense potential to become viable enterprises, which can be very successful and powerful tool in providing a community safety net and generating income for groups [143]. These groups need to be connected with the formal seed sector in order to ensure their access to the breeder and foundation seed. This will improve the sustainability of both formal and informal seed systems and increase the seed replacement rate in the areas where seed networks are not appropriately available [12]. The capacity building of such groups needs to be ascertained, thereby strengthening their capabilities, improving their decisiveness and enabling them to deliver accurate feedback to researchers [144].

It is helpful to focus on working with NGOs specifically working with women SHGs and other female farmers. These NGOs have locally strong base for promoting livelihoods and endowing the women through various interventions and femino-centric initiatives and models [145]. These models can be exploited for dissemination, up scaling and promotions of STRVs [146]. 


\subsubsection{Deploying Progressive Farmers for Sustainability of STRVs}

One of the limitations for rapid upscaling of stress tolerant rice varieties is the nonavailability of quality seed for sale during subsequent years in the areas where large demonstrations are being conducted [19]. The need is to educate some progressive farmers in quality seed production, processing, storage and overall seed entrepreneurship. These farmers too can serve as the potential sources for ensuring the local availability of quality seed $[12,147]$. This will also make the seed system sustainable in the areas where dealers networks may not be active or existing [134]. Involving farmers in seed production can serve as the most coherent approach to ensure sustainability of STRVs in the target areas. Through sustainable seed production and distribution systems, farmers can take advantage of the benefits of STRVs.

\subsubsection{Head-to-Head Trials as Efficient and Innovative Means of Demonstration} through Learning

The communication of information to farmers has been a weak link between innovation and adoption of available and step-change technologies. Although, different schools of thought have proposed different methods, the conventionally approved approach of varietal dissemination is to organize the large-scale demonstrations where some farmers cultivate the improved variety and others in the locality are asked to visit and see the outcome $[148,149]$. In these demonstrations, the farmers can witness the outcome but cannot assess the gains. Assessing gain needs to set up a control plot planted with the next best option available with the same farmer-determined farming practices $[5,150]$.

In order to overcome the limitations of field demonstrations, the head-to-head trials are conducted in the farmer's fields. These trials involve cultivation of a new variety next to the old one to compare in the same field or in two adjoining fields under the similar set of conditions $[89,151]$. Head-to-head trials improve farmer's knowledge in the selfsupervised plots. Large number of such trials for STRVs are being laid in farmers' fields that have revealed promising results against the counterfactuals in Eastern India [12,150]. These trials are being carried out through a network of KVKs apart from NGOs who have a strong presence in remote areas where extension services are not adequate. This has boosted the confidence of farmers regarding STRVs, and thereby helped to accelerate their adoption and acceptability [89].

\subsubsection{Varietal Dissemination through Mini-Kits}

Rather than accentuating on large scale cultivation in a few spots, the strategy should be to inoculate larger number of locations with a small quantity of seed of improved cultivars mostly through lead farmers $[140,152]$. New sites are selected during ensuing years, while promoting the farmer-to-farmer diffusion at the locations covered during the earlier seasons [153]. Farmer-to-farmer diffusion of seed has been observed to be an efficient strategy for both pre- and post- release dissemination. Each season, new farmers provided with seeds are encouraged to share these with other farmers during the ensuing years. This method has been found to be very effective for awareness creation, seed up-scaling and promotion of STRVs in the difficult yet highly targeted areas of Eastern India [12,154].

\subsubsection{Strategic Partnerships}

Through a top-bottom approach, the need is to involve the national agriculture system as the lead partner and facilitate the field visits of policy makers and other top officials to the demonstration plots. The meetings between officials of national agriculture system, NGO partners, seed dealers and KVKs functionaries should be ensured. This is to get the correct feedback and anticipated seed demand for framing future plans, to maintain balance in the seed system [155]. Collaborations with civil and development organizations should be ascertained through their ongoing projects on climate change, disaster management, livelihood improvement and programs looking for technologies at national and international levels. This is to ensure the efficiency in functioning [132]. The smoothing 
of international agreements on varietal release, seed-sharing and certification need to be ascertained to ensure the easy and early availability of quality seed to farmers across borders [156].

\subsubsection{Establishing the Client-Oriented Crop Cafeteria}

Crop cafeteria involves the demonstration of different crops/varieties in a specific agroecological region, offering an opportunity for the farmers to choose a suitable one. In order to ensure the faster and sustainable uptake of STRVs, the setting up of client-oriented crop cafeteria (STRV Expo) at prime locations has been advocated. The representatives from private and/or public seed sectors, and their critical market agents (like seed growers, distributors, dealers and agrovets) are invited to visit the expos. The desirable traits of different rice varieties are demonstrated in these expos [157]. This approach is intended to fast track the awareness creation and to help in building seed demand from dealers and agrovets to their respective potential suppliers (seed companies). Dealers form an important part of the participatory varietal selection and demonstration processes, where they can provide their feedback on the demand side [158].

\subsubsection{Ensuring Capacity Building}

To improve their knowledge base, rigorous and practical training to trainers on quality seed production should be imparted to the representatives from NGOs, extension workers and progressive farmers. The training ought to be conducted with the help of local resources [159]. Most illustrative extension material and literature may be distributed among the farmers to enable them to follow the recommended practices for maintaining the seed quality [154]. Training should be carried out at local levels to enhance and ensure efficient informal seed diffusion [140].

\subsubsection{Evaluation Hubs for Formalized Feedback}

In order to have a formalized and scientific approach-based feedback, the evaluation of STRVs should be carried out under the direct control of top officials from national agriculture extension system. The officials lead the hubs to evaluate the varietal trials and convey the findings to public seed sector [160]. The feedback helps in sensitizing policy makers for future course of action $[156,161]$.

\subsubsection{Cropping System-Based Targeting}

The efforts should be laid for the development and dissemination of short duration stress tolerant rice varieties. These varieties have the potential to advance the subsequent crop, thus generating a prospect for incorporating one more crop under favorable rainfed conditions [12]. Farmers could be benefitted to great extent as they can increase or even double farm production through crop intensification [162]. Sahbhagi Dhan (IR 74371-70-11 ) is an example of short duration drought tolerant rice variety that provides ample scope for crop intensification [88].

\section{Challenges and Way Forward}

Science and technology need to play an essential role in meeting the challenge of moving the globe into safe operating space where agriculture can satisfy the food needs of every single individual, especially those living in agriculturally marginal ecosystems. Science, technology and innovations coupled with strategic planning can help the world's poor to overcome the problem of poverty and hunger [3]. Although, technological innovation has contributed significantly towards the development of STRVs showing tolerance to different types of abiotic stresses, the imperative need is to ascertain strategic plans for the development of varieties possessing multiple stress tolerance.

Moreover, the most important challenge for current system of agriculture and seed production is that the dissemination and adoption STRVs is low mainly due to the lack of information and non-availability of seeds amongst farmers [5,91,163]. The existing system 
of agricultural extension and seed supply need to be aligned in a way to successfully deliver the proven stress tolerant technology to farmers. Agricultural extension system needs reformations to enhance the diffusion and adoption of STRVs. Research based strategies ought to be implemented so that STRVs are adopted at a scale where it can achieve maximal benefits. Strategic and intentional collaborations should be ensured for enhancing the diffusion of STRVs to farmers. These strategies have the potential to ensure food security especially under the climatically vulnerable agro-ecologies.

\section{Conclusions}

Under the scenario of climate change and its impact on agricultural crop productivity, the anticipated food insecurity in the future necessitates the production of a substantially large amount of food on limited resources without disturbing the ecological systems. Recent technological innovations in crop breeding have significantly contributed by developing STRVs that have the potential to ensure the food secure future sustainably. Redesigning technologies, delivery systems and policies prove to be the most effective approach for ensuring food security in the most vulnerable areas. The immense need is to set up the sustainable and resilient food production systems that are capable of ensuring food security for future generations.

Funding: This research was funded by Bill \& Melinda Gates Foundation Grant No. OPP1088843.

Institutional Review Board Statement: Not Applicable.

Informed Consent Statement: Not Applicable.

Data Availability Statement: Not Applicable.

Acknowledgments: The authors are highly thankful to Bill and Melinda Gates Foundation (BMGF) for the financial support they provided through STRASA (Stress Tolerant Rice for Africa and South Asia) project.

Conflicts of Interest: The authors declare that no conflict of interest is involved.

\section{References}

1. Thomas, K.; Dean-Hardy, R.; Lazrus, H.; Mendez, M.; Orlove, B.; Rivera-Collazo, I.; Timmons-Roberts, J.; Rockman, M.; Warner, B.P.; Winthrop, R. Explaining differential vulnerability to climate change: A social science review. Wiley Interdisciplinary Reviews. Climate Chang. 2018, 10, e565.

2. Dar, M.H.; de-Janvry, A.; Emerick, K.; Raitzer, D.; Sadoulet, E. Flood-tolerant rice reduces yield variability and raises expected yield, differentially benefitting socially disadvantaged groups. Sci. Rep. 2013, 3, 3315. [CrossRef]

3. Dar, M.H.; Waza, S.A. Science and technology: Helping to satisfy the food needs of every individual. Rice Today 2017, 16, 29.

4. Ericksen, P.J.; Ingram, J.; Liverman, D.M. Food security and global environmental change: Emerging challenges. Environ. Sci. Policy 2009, 12, 373-377. [CrossRef]

5. Zaidi, N.W.; Singh, M.; Kumar, S.; Sangle, U.R.; Singh, R.; Prasad, R.; Singh, S.S.; Singh, S.; Yadav, A.K.; Singh, A.; et al. Trichoderma harzianum improves the performance of stress tolerant rice varieties in rainfed ecologies of Bihar, India. Field Crops Res. 2018, 220, 97-104. [CrossRef]

6. Arif, M.; Ali, K.; Jan, M.T.; Shah, Z.; Jones, D.L.; Quilliam, R.S. Integration of biochar with animal manure and nitrogen for improving maize yields and soil properties in calcareous semi-arid agroecosystems. Field Crops Res. 2016, 195, 28-35. [CrossRef]

7. Fischer, R.A.; Byerlee, D.; Edmeades, G.O. Crop Yields and Global Food Security: Will Yield Increase Continue to Feed the World? ACIAR Monograph No. 158; Australian Centre for International Agricultural Research: Canberra, Australia, 2014.

8. Popp, J.; Pető, K.; Nagy, J. Pesticide productivity and food security. A review. Agron. Sustain. Dev. 2013, 33, $243-255$.

9. Bailey-Serres, J.; Fukao, T.; Ronald, P.; Ismail, A.M.; Heuer, S.; Mackill, D.J. Submergence tolerant rice: SUB1's journey from landrace to modern cultivar. Rice 2010, 3, 138-147. [CrossRef]

10. Dar, M.H.; Singh, S.; Singh, U.S.; Ismail, A.M. Stress tolerant rice varieties: Making headway in India. SATSA Mukhapatra Ann. Tech. Issue 2014, 18, 1-14.

11. Bodner, G.; Nakhforoosh, A.; Kaul, H.P. Management of crop water under drought: A review. Agron. Sustain. Dev. 2015, 35, 401-442. [CrossRef]

12. Dar, M.H.; Waza, S.A.; Shukla, S.; Zaidi, N.W.; Nayak, S.; Hossain, M.; Kumar, A.; Ismail, A.M.; Singh, U.S. Drought tolerant rice for ensuring food security in Eastern India. Sustainability 2020, 12, 2214. [CrossRef]

13. Lagorio, A.; Pinto, R.; Golini, R. Research in urban logistics: A systematic literature review. Int. J. Phys. Distrib. Logist. Manag. 2016, 46, 908-931. [CrossRef] 
14. Friday, D.; Ryan, S.; Sridharan, R.; Collins, D. Collaborative risk management: A systematic literature review. Int. J. Phys. Distrib. Logist. Manag. 2018, 48, 231-253. [CrossRef]

15. Paciarotti, C.; Torregiani, F. The logistics of the short food supply chain: A literature review. Sustain. Prod. Consum. 2020, 26, 428-442. [CrossRef]

16. Badampudi, D.; Wohlin, C.; Petersen, K. Experiences from Using Snowballing and Database Searches in Systematic Literature Studies. In Proceedings of the 19th International Conference on Evaluation and Assessment in Software Engineering, Nanjing, China, 27-29 April 2015.

17. Singh, R.; Singh, Y.; Xalaxo, S.; Verulkar, S.B.; Yadav, N.; Singh, S.; Singh, N.; Prasad, K.; Kondayya, K.; Rao, P.R.; et al. From QTL to variety-harnessing the benefits of QTLs for drought, flood and salt tolerance in mega rice varieties of India through a multi-institutional network. Plant Sci. 2016, 242, 278-287. [CrossRef]

18. Dolferus, R. To grow or not to grow: A stressful decision for plants. Plant Sci. 2014, 229, 247-261. [CrossRef] [PubMed]

19. Dar, M.H.; Chakravorty, R.; Waza, S.A.; Sharma, M.; Zaidi, N.W.; Singh, A.N.; Singh, U.S.; Ismail, A.M. Transforming rice cultivation in flood prone coastal Odisha to ensure food and economic security. Food Secur. 2017, 4, 711-722. [CrossRef]

20. Yang, X.L.; Wang, B.F.; Chen, L.; Li, P.; Cao, C.G. The different influences of drought stress at the flowering stage on rice physiological traits, grain yield, and quality. Sci. Rep. 2019, 9, 3742.

21. Gregorio, G.B. Tagging Salinity Tolerance Genes in Rice Using Amplified Fragment Length Polymorphism (AFLP); University of the Philippines: Los Baños, Philippines, 1997; 118p.

22. Ahmad, W.; Noor, M.A.; Afzal, I.; Bakhtavar, M.A.; Nawaz, M.M.; Sun, X.; Zhou, B.; Ma, W.; Zhao, M. Improvement of sorghum crop through exogenous application of natural growth-promoting substances under a changing climate. Sustainability 2016, 8 , 1330. [CrossRef]

23. Bakhtavar, M.A.; Afzal, I.; Basra, S.M.A.; Ahmad, A.H.; Noor, M.A. Physiological strategies to improve the performance of spring maize (Zea mays L.) planted under early and optimum sowing conditions. PLoS ONE 2015, 10, e0124441. [CrossRef] [PubMed]

24. Thakur, P.; Kumar, S.; Malik, J.; Berger, J.; Nayyar, H. Cold stress effects on reproductive development in grain crops: An overview. Environ. Exp. Bot. 2010, 67, 429-443. [CrossRef]

25. Raza, A.; Razzaq, A.; Mehmood, S.S.; Zou, X.; Zhang, X.; Lv, Y.; Xu, J. Impact of climate change on crops adaptation and strategies to tackle its outcome: A review. Plants 2019, 8, 34. [CrossRef] [PubMed]

26. Bouman, B.A.M.; Peng, S.; Castaoeda, A.R.; Visperas, R.M. Yield and water use of irrigated tropical aerobic rice systems. Agric. Water Manag. 2005, 74, 87-105. [CrossRef]

27. Pandey, S.; Bhandari, H. Drought: Economic Costs and Research Implications. In Drought Frontiers in Rice: Crop Improvement for Increased Rainfed Production; Serraj, R., Bennett, J., Hardy, B., Eds.; World Scientific Publishing: Singapore, 2008 ; pp. 3-17.

28. Fukao, T.; Yeung, E.; Bailey-Serres, J. The submergence tolerance regulator SUB1A mediates crosstalk between submergence and drought tolerance in rice. Plant Cell 2011, 23, 412-427. [CrossRef]

29. Ahadiyat, Y.R.; Hidayat, P.; Susanto, U. Drought tolerance, phosphorus efficiency and yield characters of upland rice lines. Emir. J. Food Agric. 2014, 26, 25-34.

30. Raman, A.; Verulkar, S.B.; Mandal, N.P.; Variar, M.; Shukla, V.D.; Dwivedi, J.L.; Singh, B.N.; Singh, O.N.; Swain, P.; Mall, A.K.; et al. Drought yield index to select high yielding rice lines under different drought stress severities. Rice 2012, 5, 1-12. [CrossRef] [PubMed]

31. Kumar, S.; Dwivedi, S.K.; Singh, S.S.; Bhatt, B.P.; Mehta, P.; Elanchezhian, R.; Singh, V.P.; Singh, O.N. Morph-physiological traits associated with reproductive stage drought tolerance of rice (Oryza sativa L.) genotypes under rainfed condition of eastern Indo-Gangetic Plains. Ind. J. Plant. Physiol. 2014, 19, 87-93. [CrossRef]

32. Kamoshita, A.; Rofriguez, R.; Yamauchi, A.; Wade, L.J. Genotypic variation in response of rainfed lowland to prolonged drought and re-watering. Plant Prod. Sci. 2004, 7, 406-420. [CrossRef]

33. Botwright-Acuna, T.L.; Latte, H.R.; Wade, L.J. Genotype and environment interactions for grain yield of upland rice backcross lines in diverse hydrological environments. Field Crops Res. 2008, 108, 117-125. [CrossRef]

34. Anjum, S.A.; Xie, X.; Wang, L.; Saleem, M.F.; Man, C.; Lei, W. Morphological, physiological and biochemical response of plant to drought stress. Afr. J. Agric. Res. 2011, 6, 2026-2032.

35. Gana, A.S. Screening and resistance of traditional and improved cultivars of rice to drought stress at Badeggi, Niger State, Nigeria. Agric. Biol. J. North. Am. 2011, 2, 1027-1031.

36. Mackill, D.J.; Coffman, W.R.; Garrity, D.P. Rainfed Lowland Rice Improvement; International Rice Research Institute: Manila, Philippines, 1996.

37. Setter, T.L.; Ellis, M.; Laureles, E.V.; Ella, E.S.; Senadhira, D.; Mishra, S.B.; Sarkarung, S.; Datta, S. Physiology and genetics of submergence tolerance in rice. Ann. Bot. 1997, 79, 67-77. [CrossRef]

38. Septiningsih, E.M.; Pamplona, A.M.; Sanchez, D.L.; Neeraja, C.N.; Vergara, G.V.; Heuer, S.; Ismail, A.M.; Mackill, D.J. Development of submergence-tolerant rice cultivars: The Sub1 locus and beyond. Ann. Bot. 2009, 103, 151-160. [CrossRef]

39. Bhowmick, M.K.; Dhara, M.C.; Singh, S.; Dar, M.H.; Singh, U.S. Improved management options for submergence-tolerant (Sub1) rice genotype in flood-prone rainfed lowlands of West Bengal. Am. J. Plant Sci. 2014, 5, 14-23.

40. Wassmann, R.; Jagadish, S.V.K.; Sumfleth, K.; Pathak, H.; Howell, G.; Ismail, A.; Serraj, R.; Redona, E.; Singh, R.K.; Heuer, S. Regional vulnerability of climate change impacts on Asian rice production and scope for adaptation. Adv. Agron. 2009, 102, 91-133. 
41. Nishiuchi, S.; Yamauchi, T.; Takahashi, H.; Kotula, L.; Nakazono, M. Mechanisms for coping with submergence and waterlogging in rice. Rice 2012, 5, 2. [CrossRef] [PubMed]

42. Adkins, S.W.; Shiraishi, T.; McComb, J.A. Submergence tolerance of rice- a new glasshouse method for the experimental submergence of plants. Physiol. Plant. 1990, 80, 642-646. [CrossRef]

43. Ram, P.C.; Singh, A.K.; Singh, B.B.; Singh, V.K.; Singh, H.P.; Setter, T.L.; Singh, V.P.; Singh, R.K. Environmental characterization of floodwater in eastern India: Relevance to submergence tolerance of lowland rice. Exp. Agric. 1999, 35, 141-152. [CrossRef]

44. Mishra, A.K.; Erickson, K.; Harris, M.; Hallahan, C.; Uematsu, H. Determinants of Farm Household Income Diversification in the United States. In Evidence from Farm-Level Data. In Proceedings of the Agricultural and Applied Economics Association Annual Meeting, Denver, CO, USA, 25-27 July 2010.

45. Das, K.K.; Panda, D.; Sarkar, R.K.; Reddy, J.N.; Ismail, A.M. Submergence tolerance in relation to variable floodwater conditions in rice. Environ. Exp. Bot. 2009, 66, 425-434.

46. Flowers, T.J.; Flowers, S.A. Why does salinity pose such a difficult problem for plant breeders? Agric. Water Manag. 2005, 78, 15-24. [CrossRef]

47. Bano, D.A.; Singh, R.K.; Singh, N.P.; Waza, S.A. Effect of Cowpea Bradyrhizobium (RA-5) on growth parameters of pigeon pea plant under various salt concentrations at different time intervals. Indian J. Ecol. 2015, 42, 179-182.

48. Reynolds, M.P.; Ortiz-Monasterio, J.I.; McNab, A. (Eds.) Application of Physiology in Wheat Breeding; D.F.: CIMMYT; International Maize and Wheat Improvement Center: Texcoco, Mexico, 2001.

49. Kamran, M.; Parveen, A.; Ahmar, S.; Malik, Z.; Hussain, S.; Chattha, M.S.; Saleem, M.H.; Adil, M.; Heidari, P.; Chen, J.T. An Overview of Hazardous Impacts of Soil Salinity in Crops, Tolerance Mechanisms, and Amelioration through Selenium Supplementation. Int. J. Mol. Sci. 2019, 21, 148. [CrossRef]

50. Reddy, I.N.B.L.; Kim, B.K.; Yoon, I.S.; Kim, K.H.; Kwon, T.R. Salt tolerance in rice, focus on mechanisms and approaches. Rice Sci. 2017, 24, 123-144. [CrossRef]

51. Ali, S.; Gautam, R.K.; Mahajan, R.; Krishnamurthy, S.L.; Sharma, S.K.; Singh, R.K.; Ismail, A.M. Stress indices and selectable traits in SALTOL QTL introgressed rice genotypes for reproductive stage tolerance to sodicity and salinity stresses. Field Crops Res. 2013, 154, 65-73. [CrossRef]

52. Bano, D.A.; Singh, R.K.; Waza, S.A.; Singh, N.P. Effect of Cowpea Bradyrhizobium (RA-5) and Burkholderia cepacia (RRE-5) on growth parameters of pigeonpea under salt stress conditions. J. Pure Appl. Microbiol. 2015, 9, 2539-2545.

53. Waza, S.A.; Jaiswal, H.K. Effect of WA cytoplasm on yield and yield attributes of rice hybrids. Oryza 2015, 52, 100-104.

54. Munns, R. Plant Adaptations to Salt and Water Stress. Differences and Commonalities. In Advances in Botanical Research; Turkan, I., Ed.; Elsevier Ltd: Amsterdam, The Netherlands, 2011; pp. 1-32. [CrossRef]

55. Todaka, D.; Nakashima, K.; Maruyama, K.; Kidokoro, S.; Osakabe, Y.; Ito, Y.; Matsukura, S.; Fujita, Y.; Yoshiwara, K.; Ohme-Takagi, M.; et al. Rice phytochrome-interacting factor-like protein OsPIL1 functions as a key regulator of internode elongation and induces a morphological response to drought stress. Proc. Natl. Acad. Sci. USA 2012, 109, 15947-15952. [CrossRef]

56. Senanayake, R.N.N.H.; Herath, H.M.V.G.; Wickramesinghe, I.P. Phenotypic screening of rice varieties for tolerant to salt stress at seed germination, seedling and maturity stages. Trop. Agric. Res. 2017, 29, 90-100. [CrossRef]

57. Singh, R.K.; Redoña, E.; Refuerzo, L. Varietal Improvement for Abiotic Stress Tolerance in Crop Plants: Special Reference to Salinity in Rice. In Abiotic Stress Adaptation in Plants; Pareek, A., Sopory, S., Bohnert, H., Eds.; Springer: Dordrecht, Germany, 2009. [CrossRef]

58. Zafar, S.A.; Hameed, A.; Nawaz, M.A.; Wei, M.A.; Noor, M.A.; Hussain, M.; Mehboob-ur, R. Mechanisms and molecular approaches for heat tolerance in rice (Oryza sativa L.) under climate change scenario. J. Integr. Agric. 2018, 17, 726-738. [CrossRef]

59. IPCC. Contribution of Working Groups I, II and III to the Fifth Assessment Report of the Intergovernmental Panel on Climate Change; Climate Change 2014 Synthesis Report; Pachauri, R.K., Meyer, L.A., Eds.; IPCC: Geneva, Switzerland, 2014; 151p.

60. Gomez-Zavaglia, A.; Mejuto, J.C.; Simal-Gandara, J. Mitigation of emerging implications of climate change on food production systems. Food Res. Int. 2020, 134, 109256. [CrossRef]

61. Wang, H.; Zhang, M.S.; Guo, R.; Shi, D.C.; Liu, B.; Lin, X.Y.; Yang, C.W. Effects of salt stress on ion balance and nitrogen metabolism of old and young leaves in rice (Oryza sativa L.). BMC Plant Biol. 2012, 12, 194. [CrossRef]

62. Aghamolki, M.T.K.; Yusop, M.K.; Oad, F.C.; Zakikhani, H.; Jaafar, H.Z.; Kharidah, S.; Musa, M. Heat stress effects on yield parameters of selected rice cultivars at reproductive growth stages. J. Food Agric. Environ. 2014, 12, 741-746.

63. Jagadish, S.V.K.; Craufurd, P.Q.; Wheeler, T.R. High temperature stress and spikelet fertility in rice (Oryza sativa L.). J. Exp. Bot. 2007, 58, 1627-1635. [CrossRef]

64. Shah, F.; Huang, J.; Cui, K.; Nie, L.; Shah, T.; Chen, C.; Wang, K. Impact of high-temperature stress on rice plant and its traits related to tolerance. J. Agric. Sci. 2011, 149, 545-556. [CrossRef]

65. Umesh, U.; Jaiswal, H.K.; Sravan, T.; Waza, S.A.; Bhardwaj, R. Estimation of genetic variability, heritability and genetic advance for yield and quality traits in some indigenous Basmati rice (Oryza sativa L.) genotypes. Int. J. Farm. Sci. 2015, 5, 32-40.

66. Shanmugavadivel, P.S.; Amitha Mishra, S.V.; Prakash, C.; Ramkumar, M.K.; Tiwari, R.; Mohapatra, T.; Singh, N.K. High resolution mapping of QTLs for heat tolerance in rice using a 5K SNP array. Rice 2017, 10, 28.

67. Barnabás, B.; Jäger, K.; Fehér, A. The effect of drought and heat stress on reproductive processes in cereals. Plant Cell Environ. 2008, 31, 11-38. [CrossRef] [PubMed] 
68. Xiao, Y.; Pan, Y.; Luo, L.; Zhang, G.; Deng, H.; Dai, L.; Liu, X.; Tang, W.; Chen, L.; Wang, G.L. Quantitative trait loci associated with seed set under high temperature stress at the flowering stage in rice (Oryza sativa L.). Euphytica 2011, 178, 331-338.

69. Zafar, S.A.; Hameed, A.; Khan, A.S.; Ashraf, M. Heat shock induced morpho-physiological response in indica rice (Oryza sativa L.) at early seedling stage. Pak. J. Bot. 2017, 49, 453-463.

70. Shi, W.; Yin, X.; Struik, P.C.; Solis, C.; Xie, F.; Schmidt, R.C.; Huang, M.; Zou, Y.; Ye, C.; Jagadish, S.V.K. High day-and night-time temperatures affect grain growth dynamics in contrasting rice genotypes. J. Exp. Bot. 2017, 68, 5233-5245. [CrossRef]

71. Díaz, S.H.; Morejón, R.; Castro, R.; Pérez León, N. Comportamiento de genotipos de arroz (Oryza sativa L.) seleccionados para tolerancia a bajas temperaturas en siembra temprana de frío. Cultiv. Trop. 2006, 27, 71-75.

72. Sravan, T.; Jaiswal, H.K.; Waza, S.A.; Priyanka, K. Analysis of variability and character association in indigenous aromatic rice (Oryza sativa L.). Electron. J. Plant Breed. 2016, 7, 159-164. [CrossRef]

73. Da-Cruz, R.P.; Milach, S.C.K.; Federizzi, L.C. Inheritance of rice cold tolerance at the germination stage. Genet. Mol. Biol. 2006, 29, 314-320. [CrossRef]

74. Najar, Z.A.; Sheikh, F.A.; Najeeb, S.; Shikari, A.B.; Ahangar, M.A.; Sheikh, G.A.; Wani, S.H. Genotypic and morphological diversity analysis in high altitude maize (Zea mays L.) inbreds under Himalayan temperate ecologies. Maydica 2018, 63, 1-7.

75. Matsuo, T.; Kumuzawa, K.; Ishii, R.; Ishihara, K.; Hirata, H. Science of the Rice Plant. Volume 2: Physiology; Food and Agriculture Policy Research Centre: Tokyo, Japan, 1995.

76. Zeng, Y.; Zhang, Y.; Xiang, J.; Uphoff, N.T.; Pan, X.; Zhu, D. Effects of low temperature stress on spikelet-related parameters during anthesis in Indica-Japonica hybrid rice. Front. Plant. Sci. 2017, 8, 1350. [CrossRef]

77. Satake, T.; Koike, S. Circular dense planting water culture of rice plants, with the purpose of obtaining many uniform panicles of main stems from a pot. Jpn. J. Crop. Sci. 1983, 52, 598-600. [CrossRef]

78. Rashid, A.; Sofi, N.R.; Shikari, A.B.; Khan, G.H.; Waza, S.A.; Sheikh, F.A.; Parray, G.A.; Bhat, M.A.; Sofi, M.; Hussain, A Developing rice hybrids for temperate conditions using three-line approach. Indian J. Genet. Plant Breed. $2019,79,25-33$.

79. Aghaee, A.; Moradi, F.; Zare-Maivan, H.; Zarinkamar, F.; Pour-Irandoost, H.; Sharif, P. Physiological responses of two rice (Oryza sativa L.) genotypes to chilling stress at the seedling stage. Afr. J. Biotechnol. 2011, 10, 7617-7621.

80. Suzuki, K.; Nagasuga, K.; Okada, M. The chilling injury induced by high root temperature in the leaves of rice seedlings. Plant. Cell Physiol. 2008, 49, 433-442. [CrossRef] [PubMed]

81. Ye, H.; Du, H.; Tang, N.; Li, X.; Xiong, L. Identification and expression profiling analysis of TIFY family genes involved in stress and phytohormone responses in rice. Plant Mol. Biol. 2009, 71, 291-305. [CrossRef]

82. Ismail, A.M.; Singh, U.S.; Singh, S.; Dar, M.H.; Mackill, D.J. The contribution of submergence-tolerant (Sub1) rice varieties to food security in flood-prone rainfed lowland areas in Asia. Field Crops Res. 2013, 152, 83-93. [CrossRef]

83. Singh, U.S.; Dar, M.H.; Singh, S.; Zaidi, N.W.; Bari, M.A.; Mackill, D.J.; Collard, B.C.Y.; Singh, V.N.; Singh, J.P.; Reddy, J.N.; et al. Field performance, dissemination, impact and tracking of submergence tolerant (Sub1) rice varieties in South Asia. SABRAO J. Breed. Genet. 2013, 45, 112-131.

84. Mackill, D.J.; Ismail, A.M.; Singh, U.S.; Labios, R.V.; Paris, T.R. Development and rapid adoption of submergence-tolerant (Sub1) rice varieties. Adv. Agron. 2012, 115, 303-356.

85. Serraj, R.; Atlin, G. Drought-Resistant Rice for Increased Rainfed Production and Poverty Alleviation: A Concept Note. In Drought Frontiers in Rice: Crop Improvement for Increased Rainfed Production; Serraj, R., Bennett, J., Hardy, B., Eds.; World Scientific Publishing: Singapore, 2008; pp. 385-400.

86. Kumar, A.; Bernier, J.; Verulkar, S.; Lafitte, H.R.; Atlin, G.N. Breeding for drought tolerance: Direct selection for yield, response to selection and use of drought tolerant donors in upland and lowland adapted populations. Field Crops Res. 2008, 107, $221-231$. [CrossRef]

87. Swamy, B.P.M.; Ahmad, H.U.; Henry, A.; Mauleon, R.; Dixit, S.; Vikra, P.; Tilatto, R.; Verulkar, S.B.; Perraju, P.; Mandal, N.P.; et al. Genetic, physiological, and gene expression analyses reveal that multiple QTL enhance yield of rice mega-variety IR64 under drought. PLoS ONE 2013, 8, e62795.

88. Basu, S.; Jongerden, J.; Ruivenkamp, G. Development of the drought tolerant variety Sahbhagi Dhan: Exploring the concepts commons and community building. Int. J. Commons 2017, 11, 144-170. [CrossRef]

89. Dar, M.H.; Zaidi, N.W.; Waza, S.A.; Verulkar, S.B.; Ahmed, T.; Singh, P.K.; Bardhan Roy, S.K.; Chaudhary, B.; Yadav, R.; Islam, M.M.; et al. No yield penalty under favorable conditions paving the way for successful adoption of flood tolerant rice. Sci. Rep. 2018, 8, 9245. [CrossRef]

90. Tester, M.; Langridge, P. Breeding technologies to increase crop production in a changing world. Science 2010, 327, 818-822. [CrossRef]

91. Emerick, K.; de-Janvry, A.; Sadoulet, E.; Dar, M.H. Technological innovations, downside risk, and the modernization of agriculture. Am. Econ. Rev. 2016, 106, 1537-1561. [CrossRef]

92. Jaiswal, S.; Gautam, R.K.; Singh, R.K.; Krishnamurthy, S.L.; Ali, S.; Sakthivel, K.; Iquebal, M.A.; Rai, A.; Kumar, D. Harmonizing technological advances in phenomics and genomics for enhanced salt tolerance in rice from a practical perspective. Rice 2019, 12, 89.

93. Ali, M.N.; Yeasmin, L.; Gantait, S.; Goswami, R.; Chakraborty, S. Screening of rice landraces for salinity tolerance at seedling stage through morphological and molecular markers. Physiol. Mol. Biol. Plants 2014, 20, 411-423. [CrossRef] 
94. Bimpong, I.K.; Manneh, B.; Sock, M.; Diaw, F.; Amoah, N.K.A.; Ismail, A.M.; Gregorio, G.; Singh, R.K.; Wopereis, M. Improving salt tolerance of lowland rice cultivar 'Rassi' through marker-aided backcross breeding in West Africa. Plant Sci. 2016, 242, 288-299.

95. Thomson, M.J.; de-Ocampo, M.; Egdane, J.; Rahman, M.A.; Sajise, A.G.; Adorada, D.L.; Tumimbang-Raiz, E.; Blumwald, E.; Seraj, Z.I.; Singh, R.K.; et al. Characterizing the saltol quantitative trait locus for salinity tolerance in Rice. Rice 2010, 3, 148-160. [CrossRef]

96. Mansuri, R.M.; Shobbar, Z.S.; Jelodar, N.B.; Ghaffari, M.R.; Nematzadeh, G.A.; Asari, S. Dissecting molecular mechanisms underlying salt tolerance in rice: A comparative transcriptional profiling of the contrasting genotypes. Rice 2019, 12, 13. [CrossRef] [PubMed]

97. Lekklar, C.; Pongpanich, M.; Suriya-arunroj, D.; Chinpongpanich, A.; Tsai, H.; Comai, L.; Chadchawan, S.; Buaboocha, T. Genome-wide association study for salinity tolerance at the flowering stage in a panel of rice accessions from Thailand. BMC Genom. 2019, 20, 76. [CrossRef]

98. Ismail, A.M.; Horie, T. Genomics, physiology, and molecular breeding approaches for improving salt tolerance. Annu. Rev. Plant Biol. 2017, 68, 405-434. [CrossRef] [PubMed]

99. Batayeva, D.; Labaco, B.; Ye, C.; Li, X.; Usenbekov, B.; Rysbekova, A.; Dyuskalieva, G.; Vergara, G.; Reinke, R.; Leung, H. Genome-wide association study of seedling stage salinity tolerance in temperate japonica rice germplasm. BMC Genet. $2018,19$. [CrossRef]

100. Zheng, H.; Wang, J.; Zhao, H.; Liu, H.; Sun, J.; Guo, L.; Zou, D. Genetic structure, linkage disequilibrium and association mapping of salt tolerance in japonica rice germplasm at the seedling stage. Mol. Breed. 2015, 35, 152-168.

101. Khan, S.; Anwar, S.; Ashraf, M.Y.; Khaliq, B.; Sun, M.; Hussain, S.; Zhi-qiang, G.; Noor, H.; Alam, S. Mechanisms and Adaptation Strategies to Improve Heat Tolerance in Rice. A Review. Plants 2019, 8, 508. [CrossRef]

102. Cheabu, S.; Panichawong, N.; Rattanametta, P.; Wasuri, B.; Kasemsap, P.; Arikit, S.; Vanavichit, A.; Malumpong, C. Screening for spikelet fertility and validation of heat tolerance in a large rice mutant population. Rice Sci. 2019, 26, 229-238. [CrossRef]

103. Bahuguna, R.N.; Jha, J.; Pal, M.; Shah, D.; Lawas, L.M.F.; Khetarpal, S.; Jagadish, S.V.K. Physiological and biochemical characterization of NERICA-L-44: A novel source of heat tolerance at the vegetative and reproductive stages in rice. Physiol. Plant. 2015, 154, 543-559. [CrossRef] [PubMed]

104. Ye, C.; Argayoso, M.A.; Redoña, E.D.; Sierra, S.N.; Laza, M.A.; Dilla, C.J.; Mo, Y.; Thomson, M.J.; Chin, J.; Delaviña, C.B.; et al. Mapping QTL for heat tolerance at flowering stage in rice using SNP markers. Plant Breed. 2012, 131, 33-41. [CrossRef]

105. Kilasi, N.L.; Singh, J.; Vallejos, C.E.; Ye, C.; Jagadish, S.V.K.; Kusolwa, P.; Rathinasabapathi, B. Heat stress tolerance in rice (Oryza sativa L.): Identification of quantitative trait loci and candidate genes for seedling growth under heat stress. Front. Plant Sci. 2018, 9, 1578. [CrossRef]

106. Govindaraj, M.; Pattanashetti, S.K.; Patne, N.; Kanatti, A. Breeding Cultivars for Heat Stress Tolerance in Staple Food Crops. In Next Generation Plant Breeding; Intech Open Limited: London, UK, 2018; pp. 45-74.

107. Jaiswal, H.K.; Waza, S.A.; Rai, V.P. Validation of Functional Markers Associated with Genes for Fragrance in Rice (Oryza sativa L.). Indian J. Plant Genet. Resour. 2019, 32, 217-222.

108. Majid, A.; Parray, G.A.; Sofi, N.R.; Khan, G.H.; Waza, S.A.; Shikari, A.B. Marker-assisted identification of potential fertility restorers for the development of three-line hybrids in rice (Oryza sativa L.). Oryza 2020, 57, 181-189. [CrossRef]

109. Ye, C.; Tenorio, F.A.; Redoña, E.D.; Morales-Cortezano, P.S.; Cabrega, G.A.; Jagadish, K.S.V.; Gregorio, G.B. Fine mapping and validating qHTSF4.1 to increase spikelet fertility under heat stress at flowering in rice. Theor. Appl. Genet. 2015, 128, 1507-1517. [CrossRef]

110. Ma, X.; Feng, F.; Wei, H.; Mei, H.; Xu, K.; Chen, S.; Li, T.; Liang, X.; Liu, H.; Luo, L. Genome-wide association study for plant height and grain yield in rice under contrasting moisture regimes. Front. Plant. Sci. 2016, 7, 1801. [CrossRef] [PubMed]

111. Joshi, M.; Singh, P.K.; Pallavi, S.; Waza, S.A.; Singh, A. Estimation of genetic diversity among the rice (Oryza sativa L.) genotypes using microsatellite markers. Indian J. Plant Genet. Resour. 2017, 30, 130-135. [CrossRef]

112. Lafarge, T.; Bueno, C.; Frouin, J.; Jacquin, L.; Courtois, B.; Ahmadi, N. Genome-wide association analysis for heat tolerance at flowering detected a large set of genes involved in adaptation to thermal and other stresses. PLoS ONE 2017, 12, e0171254. [CrossRef]

113. Majid, A.; Parray, G.A.; Wani, S.H.; Kordostami, M.; Sofi, N.R.; Waza, S.A.; Shikari, A.B.; Gulzar, S. Genome Editing and its Necessity in Agriculture. Int. J. Curr. Microbiol. Appl. Sci. 2017, 6, 5435-5443. [CrossRef]

114. Singh, S.; Ahlawat, S.; Sanwal, S. Role of ICT in Agriculture: Policy implications. Orient. J. Comp. Sci. Technol. 2017, 10, 691-697. [CrossRef]

115. Zhang, Q.; Chen, Q.H.; Wang, S.L.; Hong, Y.H.; Wang, Z.L. Rice and cold stress: Methods for its evaluation and summary of cold tolerance-related quantitative trait loci. Rice 2014, 7, 1-12. [CrossRef]

116. Lou, Q.J.; Chen, L.; Sun, Z.X. A major QTL associated with cold tolerance at seedling stage in rice (Oryza sativa L.). Euphytica 2007, 158, 87-94. [CrossRef]

117. Priyanka, K.; Jaiswal, H.K.; Waza, S.A.; Sravan, T. Response of rice seedlings to cold tolerance under boro conditions. SABRAO J. Breed. Genet. 2015, 47, 185-190.

118. Dien, D.C.; Yamakawa, T. Phenotypic variation and selection for cold-tolerant rice (Oryza sativa L.) at Germination and Seedling Stages. Agriculture 2019, 9, 162. [CrossRef] 
119. Shikari, A.B.; Najeeb, S.; Khan, G.; Mohiddin, F.A.; Waza, S.A. KASP ${ }^{\mathrm{TM}}$ based markers reveal a population sub-structure in temperate rice (Oryza sativa L.) germplasm and local landraces grown in the Kashmir valley, north-western Himalayas. Genet. Resour. Crop. Evol. 2020. [CrossRef]

120. Biswas, P.S.; Rashid, M.M.; Khatun, H.; Yasmeen, R.; Biswas, J.K. Chapter 11: Scope and Progress of Rice Research Harnessing Cold Tolerance. In Advances in Rice Research for Abiotic Stress Tolerance; Hasanuzzaman, M.M., Fujita, N.K., Biswas, J.K., Eds.; Elsevier: Amsterdam, The Netherlands, 2019; pp. 225-264.

121. Satoh, T.; Tezuka, K.; Kawamoto, T.; Matsumoto, S.; Satoh-Nagasawa, N.; Ueda, K.; Sakurai, K.; Watanabe, A.; Takahashi, H.; Akagi, H. Identification of QTLs controlling low-temperature germination of the East European rice (Oryza sativa L.) variety Maratteli. Euphytica 2016, 207, 245-254. [CrossRef]

122. Wang, X.; Zou, B.; Shao, Q.; Cui, Y.; Lu, S.; Zhang, Y.; Huang, Q.; Huang, J.; Hua, J. Natural variation reveals that OsSAP16 controls low-temperature germination in rice. J. Exp. Bot. 2018, 69, 413-421. [PubMed]

123. Jiang, L.; Liu, S.; Hou, M.; Tang, J.; Chen, L.; Zhai, H.; Wan, J. Analysis of QTLs for seed low temperature germinability and anoxia germinability in rice (Oryza sativa L.). Field Crop. Res. 2006, 98, 68-75. [CrossRef]

124. Yang, T.; Zhang, S.; Zhao, J.; Huang, Z.; Zhang, G.; Liu, B. Meta-analysis of QTLs underlying cold tolerance in rice (Oryza sativa L.). Mol. Plant Breed. 2015, 13, 1-15.

125. Ahangar, M.A.; Dar, Z.A.; Waza, S.A.; Shikari, A.B.; Sheikh, F.A.; Sapna, S.; Teeli, N.A.; Lone, A.A. Larnoo Purple: A high yielding, early maturing, cold tolerant maize line with high carotenoid and protein content. Indian J. Plant Genet. Resour. 2020, 33, 106-108. [CrossRef]

126. Zepeda, L. Agricultural Investment, Production Capacity and Productivity. In Agricultural Investment and Productivity in Developing Countries; Zepeda, L., Ed.; FAO: Rome, Italy, 2001.

127. Courtois, B.; McLaren, G.; Sinha, P.K.; Prasad, K.; Yadav, R.; Shen, L. Mapping QTL associated with drought avoidance in upland rice. Mol. Breed. 2000, 6, 55-66. [CrossRef]

128. Sarkar, R.K.; Panda, D.; Reddy, J.N.; Patnaik, S.S.C.; Mackill, D.J.; Ismail, A.M. Performance of submergence tolerant rice genotypes carrying the Sub1 QTL under stressed and non-stressed natural field conditions. Indian J. Agric. Sci. 2009, 79, 876-883.

129. Singh, S.; Mackill, D.; Ismail, A. Responses of Sub1 rice introgression lines to submergence in the field: Yield and grain quality. Field Crops Res. 2009, 113, 12-23. [CrossRef]

130. Ahangar, M.A.; Shikari, A.B.; Waza, S.A.; Sheikh, F.A.; Najeeb, S.; Teeli, N.A.; Dar, Z.A.; Lone, A.A. Shalimar Maize Hybrid 4, a Most Promising Hybrid for High Altitude Ecologies of Kashmir Valley. Curr. J. Appl. Sci. Technol. 2020, 39, $136-144$.

131. Ahmad, M.D.; Kirby, M.; Islam, M.S.; Hossain, M.J.; Islam, M.M. Groundwater use for irrigation and its productivity: Status and opportunities for crop intensification for food security in Bangladesh. Water Resour. Manag. 2014, 28, 1415-1429. [CrossRef]

132. Abebe, G.; Alemu, A. Role of improved seeds towards improving livelihood and food security at Ethiopia. Int. J. Res. Granthaalayah 2017, 5, 338-356. [CrossRef]

133. Emerick, K. Trading frictions in Indian village economies. J. Dev. Econ. 2018, 132, 32-56.

134. Chapagain, T.; Raizada, M.N. Impacts of Natural Disasters on Smallholder Farmers: Gaps and Recommendations. Agric. Food Secur. 2017, 6, 39. [CrossRef]

135. Rankin, M.; Galvez, N.E.; Santacoloma, P.; Mhlanga, N.; Rizzo, C. Public-Private Partnerships for Agribusiness Development-A Review of International Experiences; FAO: Rome, Italy, 2016; 183p.

136. Vernooy, R.; Shrestha, P.; Sthapit, B. (Eds.) Community Seed Banks: Origins, Evolution and Prospects; Routledge: Oxford, UK, 2015.

137. Rutsaert, P.; Donovan, J. Sticking with the old seed: Input value chains and the challenges to deliver genetic gains to small holder maize farmers. Outlook Agric. 2020, 49, 39-49. [CrossRef] [PubMed]

138. Odame, H.; Muange, E. Can agro-dealers deliver the green revolution in Kenya? IDS Bulletin 2011, 42, 78-89. [CrossRef]

139. Smale, M.; Simpungwe, E.; Birol, E.; Kassie, G.T.; De Groote, H.; Mutale, R. The changing structure of the maize seed industry in Zambia: Prospects for orange maize. Agribusiness 2015, 31, 132-146. [CrossRef]

140. Dar, M.H.; Waza, S.A.; Nayak, S.; Chakravorty, R.; Zaidi, N.W.; Hossain, M. Gender focussed trainings and knowledge uplifts the adoption of climate resilient seeds. Technol. Soc. 2020, 63, 101388. [CrossRef]

141. Lukuyu, B.; Place, F.; Franzel, S.; Kiptot, E. Disseminating improved practices: Are volunteer farmer trainers effective? J. Agr. Educ. Ext. 2012, 18, 525-540. [CrossRef]

142. Burgus, S.; Duysen, E. Identifying topics and dissemination methods for agricultural safety and health messages. Safety 2017, 3, 3. [CrossRef]

143. Kidder, T.; Romana, S.; Canepa, C.; Chettleborough, J.; Molina, C. Oxfam's Conceptual Framework on Women's Economic Empowerment; Oxfam: Oxford, UK, 2017.

144. Ibrahim, S.; Alkire, S. Agency and empowerment: A proposal for internationally comparable indicators. World Dev. 2007, 35, 379-403. [CrossRef]

145. Rubin, D.; Manfre, C.; Nichols-Barret, K. Handbook: Promoting Gender Equitable Opportunities in Agricultural Value Chains; USAID: Washington, DC, USA, 2009.

146. Coles, C.; Mitchell, J. Gender and Agricultural Value Chains-A Review of Current Knowledge and Practice and Their Policy Implications; ODI Paper forthcoming for un FAO sofa 2010; ODI: London, UK, 2009.

147. Waza, S.A.; Rastogi, N.K.; Verulkar, S.B.; Chandrakar, P.K. DNA fingerprinting and purity testing of the two pureline varieties of rice (Oryza sativa L.) using SSR markers. Seed Res. 2012, 40, 110-114. 
148. Emerick, K.; Dar, M.H. Farmer field days and demonstrator selection for increasing technology adoption. Rev. Econ. Stat. 2020, 1-41. [CrossRef]

149. Duflo, E.; Kremer, M.; Robinson, J. How high are rates of return to fertilizer? Evidence from field experiments in Kenya. Am. Econ. Rev. 2008, 98, 482-488. [CrossRef]

150. Dhehibi, B.; Rudiger, U.; Moyo, H.P.; Dhraief, M.Z. Agricultural Technology Transfer Preferences of Smallholder Farmers in Tunisia's Arid Regions. Sustainability 2020, 12, 421. [CrossRef]

151. Hansson, S.O. Farmers' experiments and scientific methodology. Eur. J. Philos. Sci. 2019, 9, 32. [CrossRef]

152. Veteläinen, M.; Negri, V.; Maxted, N. (Eds.) European Landraces: On-farm Conservation, Management and Use; Biodiversity Technical Bulletin; Biodiversity International: Rome, Italy, 2009.

153. Dar, M.H.; de Janvry, A.; Emerick, K.; Kelley, E.M.; Sadoulet, E. Casting a Wider Net: Sharing Information beyond Social Networks. Working paper. 2020. Available online: https://are.berkeley.edu/esadoulet/wp-content/uploads/2020/11/Castinga-wider-net.pdf (accessed on 15 January 2021).

154. Coomes, O.T.; McGuire, S.J.; Garine, E.; Caillon, S.; McKey, D.; Demeulenaere, E.; Jarvis, D.; Aistara, G.; Barnaud, A.; Clouvel, P.; et al. Farmer seed networks make a limited contribution to agriculture? Four common misconceptions. Food Policy 2015, 56, 41-50. [CrossRef]

155. Janvry, A.D.; Emerick, K.; Sadoulet, E.; Dar, M. The Agricultural Technology Adoption Puzzle: What Can We Learn from Field Experiments? FERDI Working paper 178. Policy Brief. Fondation Pour Les Etudes et Recherges sur Le Development International (FERDI). 2016. Available online: https:/ / ferdi.fr/dl/df-fp2tipEP79TxRtujbBYbr5Ke/ferdi-p178-the-agriculturaltechnologyadoption-puzzle-what-can-we-learn.pdf (accessed on 15 January 2021).

156. Singh, S.P.; Behura, D.; Kumar, S. Harmonizing Seed Policies for Better Cooperation in Rice Seed Trade between India and Bangladesh. In Proceedings of the 29th International Conference of Agricultural Economists (ICAE), Milan, Italy, 8-14 August 2015.

157. Witcombe, J.R.; Petre, R.; Jones, S.; Joshi, A. Farmer participatory crop improvement. IV. The spread and impact of a rice variety identified by participatory varietal selection. Exp. Agric. 1999, 35, 471-487. [CrossRef]

158. Dar, M.H.; de Janvry, A.; Emerick, K.; Sadoulet, E.; Wiseman, E. Private Input Suppliers as Information Agents for Technology Adoption in Agriculture. CEPR Discussion Paper, No. DP15584. Available online: https:// ssrn.com/abstract=3753989 (accessed on 15 December 2020).

159. Chi, T.T.N. Factors affecting technology adoption among rice farmers in the Mekong Delta through the lens of the local authorial managers: An analysis of qualitative data. OmonRice 2008, 16, 107-112.

160. Waddington, H.; Snilstveit, B.; Hombrados, J.; Vojtkova, M.; Phillips, D.; Davies, P.; White, H. Farmer field schools for improving farming practices and farmer outcomes: A systematic review. Campbell Syst. Rev. 2014, 6, 335. [CrossRef]

161. Anandajayaskeram, P.; Puskur, R.; Workneh, S.; Hoekstra, D. Concepts and Practices in Agricultural Extension in Developing Countries: A Source Book; IFPRI (International Food Policy Research Institute): Washington, DC, USA; ILRI (International Livestock Research Institute): Nairobi, Kenya, 2008; 275p.

162. Radanielson, A.M.; Yoichiro, K.; Palao, L.K.; Feyisa, G.; Malabayabas, A.J.; Aunario, J.K.; Garcia, C.; Balanza, J.G.; Win, K.T.; Singh, R.K.; et al. Targeting management practices for rice yield gains in stress-prone environments of Myanmar. Field Crops Res. 2019, 224, 107631. [CrossRef]

163. Waza, S.A.; Jaiswal, H.K.; Sravan, T.; Bano, D.A.; Priyanka, K.; Singh, P.K.; Umesh, U. Heterosis for yield and quality traits in rice (O. sativa L.). J. Appl. Nat. Sci. 2016, 8, 1510-1522. 